\title{
LOKALNE PRODUKTY UNIEJOWSKIE JAKO NARZĘDZIE PROMOCYJNE GMINY I PAMIĄTKA Z PODRÓŻY
}

Zarys treści: Jednym z trendów współczesnej turystyki jest zainteresowanie dziedzictwem lokalnym i regionalnym. Nowe trendy konsumenckie, jak etnocentryzm, rosnące zainteresowanie produktami rodzimymi czy ekologizacja produkcji dobrze widoczne są na targach, jarmarkach i kiermaszach, na których konsumenci poszukują unikatowych produktów powstałych z surowców wiadomego pochodzenia, o niepowtarzalnych walorach organoleptycznych. W przypadku gminy Uniejów rynek produktów lokalnych jest w fazie kształtowania się, aczkolwiek zarówno władze, jak i przedsiębiorcy dostrzegają w nich skuteczne narzędzie budowania marki turystycznej oraz czynnik promocyjny. Produkty uniejowskie zaczynają również funkcjonować jako pamiątka turystyczna, a wyniki sprzedażowe potwierdzają ich siłę marketingową, co w warunkach popytu na dobra rodzime stwarza nowe perspektywy. Celem opracowania jest ukazanie poprzez wybrane przykłady uniejowskich wyrobów, w jaki sposób można wykorzystać zasoby lokalne oraz jak oferta produktowa wpływa na kształtowanie wizerunku i popularyzowanie oferty turystycznej gminy Uniejów.

Słowa kluczowe: marketing lokalny, produkt lokalny, promocja, Uniejów

\section{WPROWADZENIE}

Potencjał gospodarczy współczesnej turystyki sprawił, że sektor ten traktowany jest obecnie w kategorii globalnej siły ekonomicznej ${ }^{1}$, która pobudza i kształtuje rozwój na różnych szczeblach, od krajowego po lokalny. Aktywizacja

* Agnieszka Owczarek, mgr, absolwentka, Uniwersytet im. A. Mickiewicza w Poznaniu, Instytut Filologii Romańskiej; Urząd Miasta w Uniejowie, Dział Promocji, ul. Bł. Bogumiła 13, 99-210 Uniejów, e-mail: agnieszka.owczarek@uniejow.pl

1 S. Milne, I. Ateljevic, Tourism, economic development and the global-local nexus: theory embracing complexity, „Tourism Geographies” 2001, t. 3, nr 4, s. 369-393. 
obszarów lokalnych uwarunkowana jest przede wszystkim potencjałem oraz możliwościami tkwiącymi w inicjatywach i zbiorowym wysiłku miejscowej społeczności, ale wynika również z rosnącego zainteresowania lokalnością i regionalnością. Owa „moda” kieruje do rozmaitych zakątków w poszukiwaniu unikatowości i oryginalności, która charakteryzuje kultury lokalne. Coraz chętniej turyści sięgają po miejscowe artykuły. Próbują np. lokalnych kulinariów powstałych na bazie ekologicznych składników, ponieważ cechują się one określonymi parametrami, ale także dlatego, że poprzez produkty te mogą doświadczyć tego, co charakterystyczne dla danego obszaru, zagłębić się w dziedzictwo, historię i miejscową tradycję. Paradoksalnie w dobie globalizacji to właśnie lokalność nabiera znaczenia. Miejscowe wyroby są odpowiedzią na coraz bardziej wyrafinowane gusta klientów i w odróżnieniu od tych pochodzących z masowej produkcji, stają się wyznacznikiem i symbolem jakości. W efekcie oferta produktowa obok walorów przyrodniczych czy atrakcji antropogenicznych staje się elementem strategii rozwoju i marketingu lokalnego, a stosunkowo niewielkie obszary, jak gminy i powiaty, mają szansę stać się atrakcyjną destynacją turystyczną.

Głównym czynnikiem stymulującym rozwój gminy Uniejów są działania związane z wydobyciem i eksploatacją wód termalnych oraz ich wykorzystaniem do celów ciepłowniczych, balneoterapeutycznych, rekreacyjnych, kosmetycznych, spożywczych i podgrzewania gruntu. Uniejowska solanka cechuje się właściwościami leczniczymi i pielęgnacyjnymi potwierdzonymi świadectwami i certyfikatami. Umiejętne wykorzystanie potencjału wód podziemnych, poprzez realizację licznych inwestycji samorządowych i prywatnych, stało się determinantą rozwoju gminy i dało podwaliny pod prężnie rozwijającą się turystykę uzdrowiskową i sportowo-rekreacyjną wraz z bogatym zapleczem noclegowym i gastronomicznym ${ }^{2}$.

$\mathrm{Na}$ fali tego trendu zarówno uniejowskie władze lokalne, jak i przedsiębiorcy dostrzegli możliwości tkwiące również w produktach lokalnych, które obecnie są skuteczną i atrakcyjną wizytówką wielu miejscowości i czynnikiem wzmacniającym funkcję turystyczną. Rozpoczęto więc prace nad stworzeniem wyrobów, które jako dopełnienie i interesujący komponent istniejącej oferty turystycznej w perspektywie długofalowej już są i będą wyróżnikiem Uniejowa i elementem kształtującym jego wizerunek i rozpoznawalność.

Celem artykułu jest przedstawienie flagowych wyrobów uniejowskich, omówienie ich istoty oraz wskazanie kluczowych atutów i barier w procesie kształtowania się lokalnego rynku w gminie Uniejów. Przyjęto założenie, że wyroby lokalne są skutecznym narzędziem promocyjnym i stanowią czynnik napędza-

2 A. Kulawiak, T. Rachwał, K. Smętkiewicz, Wpływ inwestycji infrastrukturalnych, przemystowych i mieszkaniowych na rozwój układów lokalnych na przykładzie gminy Uniejów w województwie tódzkim, „Prace Komisji Geografii Przemysłu Polskiego Towarzystwa Geograficznego” 2018, t. 32, nr 3, s. 69-97. 
jący rozwój lokalny, pobudzający aktywność poznawczą turystów i wpływający na popularyzowanie oferty turystycznej gminy, zwłaszcza w kontekście pamiątki z podróży. Do przedstawienia problematyki artykułu posłużono się odpowiednimi pozycjami literatury przedmiotu, zaś dla lepszego zobrazowania zagadnienia uniejowskich produktów lokalnych wykorzystano informacje uzyskane z działów marketingu wybranych obiektów turystycznych w Uniejowie.

\section{ISTOTA PRODUKTÓW LOKALNYCH W KONTEKŚCIE ZRÓWNOWAŻONEGO ROZWOJU LOKALNEGO}

Produkty lokalne według M. Czerwińskiej-Jaśkiewicz (2013) to wyroby lub usługi wytwarzane lub proponowane w określonym regionie, odwołujące się do jego tradycji, kultury, historii, bazujące na jego surowcach i walorach przyrodniczych, opracowane i przygotowane przez mieszkających tam ludzi ${ }^{3}$. Często nawiązują do jakiejś specyficznej cechy danego obszaru; tym samym w naturalny sposób eksponują i promują tę cechę, a jednoczenie zacieśniają związek z regionem i powodują, że społeczność się z nimi utożsamia.

Zasięg produktów lokalnych ogranicza się zazwyczaj do niewielkiej przestrzeni geograficznej. Powstają one na bazie lokalnych i regionalnych zasobów, a następnie oferowane są w sposób niemasowy. Produkty lokalne są także przyjazne dla środowiska, zarówno na etapie ich powstawania, jak i dystrybucji.

Szczególnymi typami produktów lokalnych są produkty regionalne i tradycyjne. Produkty regionalne to dobra lub usługi wytwarzane wyłącznie w niektórych regionach, a ich nazwę i technologię produkcji poddano ochronie prawnej. Zabezpieczenie prawne w wypadku tych produktów polega m.in. na przyznaniu im określonego oznaczenia, w tym tzw. Chronionego Oznaczenia Geograficznego (ang. PDO - Protected Designation of Origin), przyznawane produktowi, którego co najmniej jedna faza wytwarzania odbywa się na danym terenie, bądź Chronionej Nazwy Pochodzenia (ang. PGI - Protected Geographical Indicators) przyznawane tylko takiemu produktowi, którego wszystkie surowce pochodzą z określonego obszaru i wszystkie fazy wytwarzania mają miejsce na tym obszarze ${ }^{4}$. Renoma tych produktów wiąże się zatem $\mathrm{z}$ regionem, z którego pochodzą.

Inną formą produktów lokalnych są produkty tradycyjne, wytwarzane tradycyjnymi metodami, odwołujące się do dziedzictwa danego regionu, których

3 M. Czerwińska-Jaśkiewicz, Znaczenie produktów lokalnych w różnicowaniu oferty turystycznej regionu, „Zeszyty Naukowe Uniwersytetu Szczecińskiego. Problemy Zarządzania, Finansów i Marketingu" 2013, nr 30, s. 306.

4 Jaka jest różnica pomiędzy produktem regionalnym a produktem tradycyjnym?, 2016 http://szlakiembeskidu.pl/2-uncategorised/244-jaka-jest-roznica-pomiedzy-produktem-tradycyjnym-a-regionalnym.html [dostęp: 13.08.2020]. 
receptura przekazywana jest z pokolenia na pokolenie. Takie produkty mogą wykazywać związek z regionem, ale ich specyfika uwarunkowana jest przede wszystkim tradycją miejsca, z którego się wywodzą. Również produkty tradycyjne potwierdzane są tzw. Świadectwem Szczególnego Charakteru (ang. TSG - Traditional Speciality Guaranteed) $)^{5}$.

Wreszcie produkty lokalne to wszelkie inne dobra i usługi, które nawet jeśli nie są uznane przez opinię publiczną i nie mają potwierdzenia w stosownych certyfikatach, odwołują się do określonego regionu i współtworzą jego unikatową ofertę. W świetle powyższego za produkty lokalne można uznać: produkty spożywcze, rękodzieło, wyroby kosmetyczne, usługi oparte na lokalnym dziedzictwie (np. warsztaty, zajęcia edukacyjno-kulturowe), ale także lokalne wydarzenia (festyny, jarmarki, festiwale, obrzędy itp.) ${ }^{6}$. Według A. Kaczmarka (2002) produkty lokalne mogą być odrębnym produktem turystycznym funkcjonującym samodzielnie jako dobro materialne - np. pamiątka $z$ wakacji (lokalne specjały przywożone z podróży dla własnych potrzeb lub jako prezenty dla najbliższych) lub składowa bardziej skomplikowanych produktów, których przykładem są wydarzenia, szlaki kulturowe lub tematyczne, pozwalające na łączenie w sposób synergiczny miejsc i obiektów według ustalonego kryterium tematycznego ${ }^{7}$.

Wspólnym elementem produktów lokalnych, niezależnie od rodzaju, jest specyficzny i niepowtarzalny charakter oraz związek z danym regionem i jego kulturą. Są one nieodłączną częścią bogactwa i dziedzictwa danego terytorium oraz stanowią o jego wartości. Dla miejscowej społeczności wytwarzanie rodzimych dóbr jest wyrazem przynależności do swej małej ojczyzny. Mieszkańcy coraz częściej identyfikują się z nimi i czynią zeń własny atrybut, a podtrzymując tradycje lokalne, chronią jednocześnie własne dziedzictwo i wzmacniają poczucie lokalnej tożsamości.

Produkty lokalne niosą ze sobą wiele pozytywnych wartości, funkcjonują m.in. jako narzędzie wspierające i wzbogacające ofertę turystyczną; stają się same w sobie atrakcją turystyczną - pobudzają aktywność poznawczą turystów jako czynnik dopełniający wizerunek miejsca, odsyłając do jego historii, tradycji, kultury. Ponadto produkty lokalne coraz częściej są nabywane przez turystów jako pamiątka. Tym samym oprócz oczywistych względów ekonomicznych produkty te odgrywają ogromną rolę w kształtowaniu geografii ruchu turystycznego, umożliwiają identyfikację miejscowości i regionów, określają ich tożsamość oraz

5 Tamże.

6 Produkt lokalny, 2020, https://pl.wikipedia.org/wiki/Produkt_lokalny [dostęp: 13.08.2020].

7 J. Kaczmarek, A. Stasiak, B. Włodarczyk, Produkt turystyczny, [w:] A. Stasiak (red.), Turystyka i hotelarstwo, Wyd. Wyższej Szkoły Turystyki i Hotelarstwa, Łódź 2002, s. 35. 
wizerunek (image $)^{8}$. Innymi słowy wyroby lokalne stanowią wyróżnik i wizytówkę danego obszaru jako unikatowy i reprezentatywny przykład dorobku kulturowego.

Wreszcie rozwój produktów lokalnych przynosi wymierne korzyści, zarówno w sferze gospodarczej (powstawanie nowych firm, wzrost dochodów), jak i społecznej (tworzenie nowych miejsc pracy, przywiązanie do regionu i podtrzymywanie więzi społecznych, wzmocnienie poczucia tożsamości lokalnej). Produkty lokalne stwarzają zatem szansę na poprawę sytuacji ekonomicznej i umożliwiają realizowanie idei zrównoważonego rozwoju. Stanowią inwestycję w przyszłość i są stymulatorem do osiągania korzyści społeczno-gospodarczych, a uwzględniając zmieniające się trendy i rosnący popyt na wyjazdy zawierające elementy kultury, historii odwiedzanych miejsc - mogą przyczyniać się do zwiększenia popularności regionu oraz rozwoju jego funkcji turystycznej ${ }^{9}$.

\section{UWARUNKOWANIA HISTORYCZNO-GEOGRAFICZNE POWSTANIA OFERTY WYROBÓW LOKALNYCH W UNIEJOWIE}

Uniejów w swej bogatej, wielowiekowej historii wykazuje wiele przesłanek dla posiadania produktów lokalnych. Korzystne warunki przyrodnicze zadecydowały o osadnictwie na ziemi uniejowskiej już w wiekach średnich; po jednej stronie rzeki ulokowano zamek obronny, zaś po przeciwległej stronie Warty założono miasto. Był to teren uprzywilejowany pod względem lokalizacyjnym, komunikacyjnym i obronnym; innymi słowy Uniejów był ośrodkiem o ważnym znaczeniu strategicznym. Pod względem gospodarczym na rozwój i charakter miasta niewątpliwie wpłynęła obecność arcybiskupów gnieźnieńskich oraz kult św. Bogumiła, którego upowszechnienie w XV stuleciu wywołało silny ruch pątniczy oraz obecność rzemieślników.

Potwierdzenie powyższego znajdziemy w słowach L.P. Witkowskiego, który wspomina, że, w XIV w. Uniejów byt jednem z porzadniejszych miast w Polsce [...], posiadat wspaniaty i obronny nad Warta zamek, kilka fabryk (z tych fabryki płótna najwięcej się wstawiały) oraz wiele rzemieślników, których tutaj dobroczynne królów przywileje znęcaty. Posiadat nadto [...] pięć kościołów z nich jeden pod wezwaniem Maryi Panny oddany byt Kanonikom regularnym, drugi zaś Św. Mikołaja Benedyktynom, pod zwierzchnictwem Opatów tynieckich ${ }^{10}$.

8 Z. Kruczek, Polska geografia atrakcji turystycznych, Wyd. Proksenia, Kraków 2011, s. $12-14$.

9 A. Nizioł, Rola produktów lokalnych w rozwoju funkcji turystycznej regionu na przyktadzie Podkarpacia, „Annales Universitatis Mariae Curie-Skłodowska, sectio B - Geographia, Geologia, Mineralogia et Petrographia” 2016, t. LXXI, nr 2, s. 105.

${ }^{10}$ L.P. Witkowski, Biblioteka Warszawska, pismo poświęcone naukom, sztukom i przemysłowi, Drukarnia Gazety Codziennej, tom drugi, Warszawa 1855, s. 411. 
Istnienie wspólnoty benedyktyńskiej miało istotny wpływ nie tylko na życie religijne. Bracia odkrywali i doskonalili uprawy ziemi i roślin, co prowadziło do rozwoju rolnictwa. To dzięki zakonowi na terenie ówczesnego Uniejowa istniały dwa szpitale ${ }^{11}$, których istnienie oddziaływało na rozwój miasta i kształtowanie się jego charakteru.

Pomimo sprzyjających historycznie okoliczności, Uniejów nie posiada wyrobów z wielowiekową czy wielopokoleniową tradycją, które mogłyby stać się produktem markowym, firmującym gminę na kształt krakowskiego obwarzanka lub podhalańskiego oscypka.

Przyczyn tego stanu rzeczy można upatrywać przede wszystkim w niekorzystnym położeniu administracyjnym. Uniejów, mimo swego centralnego usytuowania, z dawien dawna był miejscem pogranicza, łączącego ziemię łaską z ziemią łęczycką, a bardziej współcześnie - miastem na styku województw łódzkiego i wielkopolskiego. Miejsce to cechowała różnorodność kulturowa, choćby z uwagi na wpływy pruskie, rosyjskie i żydowskie ${ }^{12}$. Położenie geograficzne Uniejowa, burzliwa historia oraz współistnienie kultur z jednej strony dawało rozległe możliwości, ale też ograniczyło kształtowanie się własnej tożsamości.

Czasy bardziej współczesne również nie były łaskawe dla powstawania produktów uniejowskich. Zarówno dotkliwe skutki II wojny światowej, jak i lata powojenne mocno zachwiały tożsamością i ciągłością kultury lokalnej. Zmiany ustrojowe i nastanie nowego reżimu przywiodło ze sobą m.in. tendencję do unifikowania produkcji przemysłowej i rolniczej, a przywiązanie i kultywowanie tradycji piętnowano jako wyraz prowincjonalności, zacofania i nienadążania za postępem ${ }^{13}$.

Polityka rządów komunistycznych nie sprzyjała posiadaniu własności i prowadzeniu prywatnej działalności, doprowadzając do zaniku wielu rzemiosł oraz umiejętności wytwarzania pewnych produktów. Procesy kolektywizacji i nacjonalizacji zrujnowały tradycyjny system nauki nowych kadr, które mogłyby zastąpić w przyszłości starych mistrzów ${ }^{14}$. Rzemiosło, które w dziejach historycznych było istotnym czynnikiem miastotwórczym, zostało więc zdegradowane, a tradycyjne cechy ograniczyły się do funkcji reprezentacyjnej. Ich przedstawiciele uświetniają

${ }^{11}$ Pierwszy szpital powstał w roku 1283 przy kościele św. Ducha. Drugi założono z myślą o księżach seniorach i przetrwał do XVIII w., gdy został całkowicie strawiony przez płomienie w wyniku pożaru. J. Szymczak, Uniejów do schyłku XVI wieku, [w:] J. Szymczak (red.), Uniejów. Dzieje miasta, Wyd. Towarzystwa Przyjaciół Uniejowa, Łódź-Uniejów 1995, s. 59-70.

${ }^{12}$ Od 1793 r. Uniejów znajdował się w zaborze pruskim, od 1807 r. - w Księstwie Warszawskim, a od 1815 r. - w zaborze rosyjskim (Królestwo Polskie). W 1939 r. w Uniejowie żyło 1400 Żydów, co stanowiło 40\% ogółu mieszkańców, Historia społeczności, 2020.

13 A. Sieczko, Tworzenie rynku produktów tradycyjnych i regionalnych, „Zeszyty Naukowe SGGW w Warszawie. Problemy Rolnictwa Światowego" 2008, t. 4, nr 19, s. 397.

${ }^{14}$ A. Suliborski, Gospodarka $i$ warunki bytowe po II wojnie światowej, [w:] J. Szymczak (red.), Uniejów. Dzieje miasta, Wyd. Towarzystwa Przyjaciół Uniejowa, Łódź-Uniejów 1995, s. 319. 
obecnie uczestnictwem i sztandarami obchody świąt kościelnych czy ważnych uroczystości państwowych.

Promowana powszechnie gospodarka nakazowo-rozdzielcza i wprowadzenie Państwowych Gospodarstw Rolnych skutkowało ograniczoną dostępnością wielu produktów na rynku. Wprawdzie wymuszało to podjęcie pewnych działań, jak choćby tzw. świniobicie i wyrób domowych wędlin czy coroczne przygotowywanie przetworów zimowych, ale jednocześnie prowadziło do zapominania tradycyjnych receptur i metod produkcji ${ }^{15}$. Konsekwencją takiego stanu rzeczy było ustawiczne zmniejszanie różnorodności i możliwości przywracania przedwojennych tradycji. Należy również podkreślić, że chociaż dominantą gospodarczą Uniejowa jest rolnictwo sięgające korzeniami początków miasta (wydawać by się więc mogło, że powinno cechować się pewnymi tradycjami), suma kilku czynników sprawiła, że gospodarstwa rolne miały charakter raczej zaopatrzeniowy, wspomagający dochody o proweniencji innej niż działalność rolnicza. Mowa przede wszystkim o specyfice gruntów polegającej na ich rozdrobieniu ${ }^{16}$. W obrębie gminy Uniejów do dziś zlokalizowane są głównie małe i średnie gospodarstwa o dominującej średniej jakości gleb i braku wyraźnego wyspecjalizowania.

W odniesieniu do przemysłu sektor ten nigdy nie odgrywał ważniejszej roli w rozwoju gospodarczym miasta. Istniejące na terenie Uniejowa zakłady w latach 70. i 80. XX w. reprezentowały przede wszystkim branże spożywcze i pełniły funkcję lokalnych centrów obsługi rolnictwa. W mieście działał m.in. zakład mleczarski, młyn, rozlewnia wód gazowanych i napojów oraz gorzelnia i rozlewnia spirytusu w Czepowie, jednak nadrzędną funkcją zakładów było zaspokojenie bieżących potrzeb mieszkańców oraz rola zaplecza rolniczego dla zlokalizowanych na terenie gminy wsi ${ }^{17}$.

Sytuacji nie poprawiły zmiany ustrojowe na przełomie lat 80 . i 90 ., co więcej pogłębiło się jeszcze malejące zainteresowanie produktami lokalnymi. Na rynku pojawiła się żywność wysoko przetworzona, gdzie wady jakości były niwelowane przez substancje chemiczne, takie jak: barwniki, substancje zapachowe, smakowe i konserwanty. Mimo to konsumenci decydowali się na nie ze względu na przystępną cenę, co było kluczowym kryterium przy niskiej dochodowości gospodarstw.

Impulsem do odwrotu na rzecz jakości stało się polepszenie sytuacji materialnej oraz wzrost świadomości na temat zdrowego stylu życia. Istotną rolę w tym procesie odegrała akcesja Polski do Unii Europejskiej w 2004 roku $^{18}$. UE nadała nowe znaczenie dziedzictwu regionalnemu, jednym z jej priorytetów była ochrona

${ }^{15}$ A. Sieczko, Tworzenie rynku..., s. 400.

16 A. Suliborski, Gospodarka i warunki bytowe..., s. 310.

17 Tamże, s. 319.

${ }^{18}$ Polska w Unii Europejskiej, 2020, https://pl.wikipedia.org/wiki/Polska_w_Unii_Europejskiej [dostęp: 13.08.2020]. 
żywności i agroturystyka w ramach wsparcia polityki rozwoju obszarów wiejskich, zaś na projekty służące jej rozwojowi można było otrzymać wsparcie finansowe ${ }^{19}$.

Dla gospodarki Uniejowa punktem zwrotnym było wybudowanie i uruchomienie w 2008 r. Kompleksu termalno-basenowego „Termy Uniejów” oraz jego sukcesywna rozbudowa w latach 2012 i 2019 i uzyskanie statusu uzdrowiska w roku 2012. Liczne inwestycje samorządowe i prywatne, przeprowadzone w latach 2007-2019 przy wsparciu funduszy unijnych w zakresie infrastruktury technicznej, drogowej, mieszkaniowej, rekreacyjnej i turystycznej, uczyniły turystykę głównym czynnikiem rozwoju miasta ${ }^{20}$.

Równolegle do realizowanych projektów inwestycyjnych postanowiono również wykorzystać potencjał tkwiący w zasobach lokalnych i rozpoczęto prace nad stworzeniem oferty artykułów uniejowskich dla wzmocnienia funkcji turystycznej. W proces ich kreowania zaangażowały się władze lokalne, przedsiębiorcy i mieszkańcy gminy. Postanowiono połączyć siły miejscowych decydentów, lokalnych liderów oraz spółek, m.in. PGK „Termy Uniejów” Sp. z o.o. i Geotermia Uniejów im. S. Olasa Sp. z o.o., a także nawiązywać liczne kontakty i współpracę z przedsiębiorcami w skali regionalnej, krajowej i międzynarodowej, czy też z instytucjami naukowo-badawczymi i innymi samorządami w kraju i za granicą, aby korzystać $\mathrm{z}$ ich doświadczeń i wdrażać jak najlepsze rozwiązania na potrzeby rozwoju gminy Uniejów.

\section{PRZEGLĄD PRODUKTÓW LOKALNYCH Z UNIEJOWA}

W celu przedstawienia aktualnego asortymentu produktów lokalnych Uniejowa skupiono się na głównych artykułach, które można uznać za najbardziej charakterystyczne i które są najskuteczniejszym narzędziem w promocji gminy oraz katalizatorem rozwoju lokalnej przedsiębiorczości.

Wzięto pod uwagę informacje uzyskane z działów marketingu następujących firm i instytucji: PGK „Termy Uniejów” Sp. z o.o., Over Group Sp. z o.o., Urząd Miasta w Uniejowie, Geotermia Uniejów im. S. Olasa Sp. z o.o., Medical Spa Hotel Lawendowe Termy i Browar Wiatr.

W analizie ujęto głównie artykuły spożywcze, m.in. Ogórek Termalny z Uniejowa, soki, wodę mineralną, piwo itp. oraz kosmetyki, innymi słowy wyroby, które rejestrują najwyższe wskaźniki sprzedażowe. Podstawowym celem przeprowadzonej analizy było zapoznanie się z informacjami dotyczącymi kanałów i miejsc dystrybucji, zasięgu i danych sprzedażowych dla lepszego zobrazowania skali zjawiska.

${ }^{19}$ M. Bednarek-Szczepańska, J. Bański, Lokalizacyjne uwarunkowania oferty gospodarstw agroturystycznych w Polsce, „Przegląd Geograficzny” 2014, t. 2, nr 86, s. 244.

${ }^{20}$ A. Kulawiak, T. Rachwał, K. Smętkiewicz, Wpływ inwestycji infrastrukturalnych..., s. 69-97. 
Wprawdzie żadna z wyżej wymienionych firm nie prowadzi odrębnych badań opiniotwórczych na temat oferowanych produktów, jednakże na podstawie pośrednich i bezpośrednich kontaktów z klientami udało się pozyskać informacje na temat oceny jakości, ceny oraz postaw społecznych wobec uniejowskich wyrobów. W przeprowadzonych badaniach posłużono się metodą wywiadu bezpośredniego, przeprowadzonego z osobami odpowiedzialnymi za sprzedaż i marketing produktów w danych firmach.

\section{KOSMETYKI NA BAZIE WODY TERMALNEJ}

Walory termiczne i chemiczne występujących na terenie Uniejowa wód zainspirowały przedstawicieli władz gminy Uniejów, osoby zarządzające spółkami Geotermia Uniejów i Termy Uniejów do rozpoczęcia starań nad opracowaniem markowych produktów opartych na bazie miejscowej wody termalnej. Wprawdzie urzeczywistnienie pomysłu, który wymagał przeprowadzenia wielu badań, znalezienia partnera do uruchomienia linii produkcyjnej i wdrożenia strategii marketingowej wymagało czasu, ale wysiłki opłaciły się i w 2017 roku wprowadzono do sprzedaży pierwszą odsłonę kosmetyków termalnych, powstałą jako owoc kooperacji z firmą kosmetyczną z regionu - Over Group Sp. z o.o. Zaprezentowane wyroby zaskoczyły odbiorców od samego początku, nie tylko ze względu na skład produktów, ale także dlatego, że oprócz linii pielęgnacyjnej do ciała pojawiła się seria dedykowana zwierzętom ${ }^{21}$. W 2019 roku asortyment kosmetyków powiększył się o nowe produkty. Potencjał surowca skłonił firmę kosmetyczną do dalszych badań nad opracowaniem produktu przeznaczonego do zastosowania w profilaktyce łuszczycy i atopowego zapalenia skóry22 (ryc. 1).

$\mathrm{Z}$ danych pozyskanych $\mathrm{z}$ działów marketingu obecnych firm zajmujących się dystrybucją, a więc PGK „Termy Uniejów” i firmy Over Group Sp. z o.o. wynika, że wyroby kosmetyczne na bazie wody termalnej znalazły uznanie klientów. Obie linie kosmetyków dostępne są w sprzedaży bezpośredniej oraz sklepie internetowym. Do czasu wybuchu pandemii w marcu 2020 roku, bezdyskusyjny prym wiodła sprzedaż bezpośrednia. Sprzedaż online wynosiła zaledwie kilka procent, w sierpniu 2020 r. wzrosła do ponad $10 \%$.

$\mathrm{Na}$ terenie Uniejowa dystrybucja prowadzona jest w następujących obiektach: Kompleksie termalno-basenowym „Termy Uniejów”, ApartHotelu, Hotelu Medical Spa Lawendowe Termy, Domu Pracy Twórczej, Zamku Arcybiskupów Gnieźnieńskich oraz w Zagrodzie Młynarskiej.

${ }^{21}$ M. Bartosiak, Termalne kosmetyki nowym produktem regionalnym, 2017, https://uniejow. pl/aktualnosci/termalne-kosmetyki-nowym-produktem-regionalnym.html [dostęp: 7.06.2020].

${ }^{22}$ J. Gontarz, Solanka w produktach geotermalnych, „Gorące Źródła. Magazyn Term Uniejów” 2017, s. 24-25. 

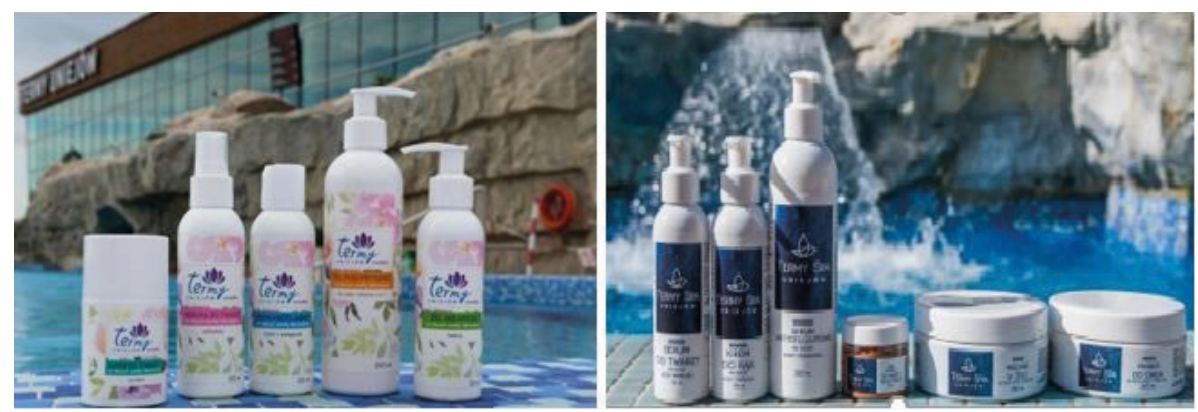

Ryc. 1. Kosmetyki termalne

Źródło: materiały udostępnione przez Geotermię Uniejów im. S. Olasa

Najwyższa sprzedaż rejestrowana w punktach stacjonarnych dotyczy obiektów o większych możliwościach recepcyjnych, tj. w Kompleksu termalno-basenowego „Termy Uniejów” oraz ApartHotelu, które odpowiadają za ok. 60\% całej sprzedaży.

Jeśli chodzi o sprzedaż internetową, kosmetyki uniejowskie na tle innych, dostępnych na stronie internetowej www.kosmetykitermalne.pl, cieszą się wyższą popularnością. Swoją renomę zawdzięczają głównie surowcowi, na bazie którego powstały, a więc wodzie termalnej, ale również pozytywnym skojarzeniom związanym z Uniejowem i jego uzdrowiskowym charakterem.

O ile sprzedaż bezpośrednia dotyczy klientów przebywających w Uniejowie, sprzedaż internetowa obejmuje zarówno nowych, jak i stałych klientów. Do nowych klientów należą głównie osoby, które odwiedziły osobiście Termy Uniejów lub o nich słyszały oraz te, które poszukują innowacyjnych rozwiązań technologii produkcji i naturalnych, zdrowych produktów.

Kosmetyki wzbudzają również duże zainteresowanie na targach branżowych, np. turystycznych, kiermaszach i innych imprezach wystawienniczych. Dotychczas nie prowadzono badań w zakresie opinii na temat kosmetyków, jednak klienci, np. w kontakcie z działem sprzedaży, często sami bardzo pozytywnie je opiniują.

Kolejna kwestia dotyczyła ważnego narzędzia marketingu, czyli ceny produktu. Cena jest źródłem informacji dla potencjalnego klienta. Zbyt wysoka może odstraszyć, a zbyt niska wywołać wątpliwości co do jakości produktu. Kosmetyki termalne na tle innych dostępnych $w$ drogeriach są istotnie nieco droższe. Jak się jednak okazuje, w tym przypadku cena nie jest zbyt wygórowana w stosunku do jakości, a klienci korzystają często z możliwości zakupu całych zestawów, co pozwala obniżyć koszty. Można więc wyciągnąć wniosek, że cena kosmetyków termalnych, zarówno jako preparatów użytkowych czy też pamiątki turystycznej, jest akceptowana. 


\section{OGÓREK TERMALNY Z UNIEJOWA I INNE PRODUKTY SPOŻYWCZE}

Uniejowska woda geotermalna znalazła zastosowanie także w przemyśle spożywczym. Równolegle do prezentowanych w 2017 roku kosmetyków odbyła się premiera pierwszego produktu spożywczego opartego na bazie uniejowskiej solanki, którym jest Ogórek Termalny z Uniejowa ${ }^{23}$ (ryc. 2).

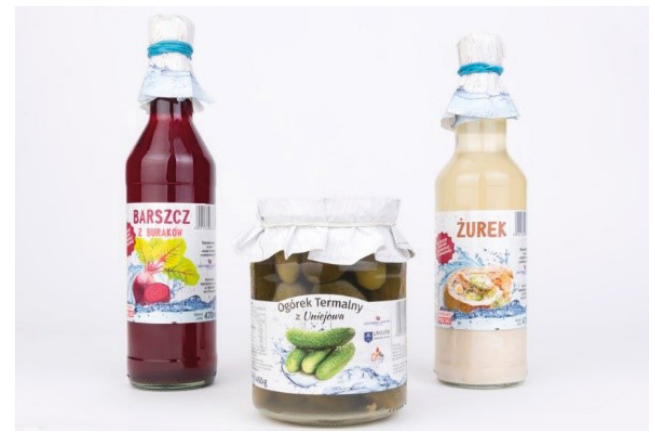

Ryc. 2. Ogórek Termalny z Uniejowa, barszcz czerwony i żurek Źródło: materiały udostępnione przez Geotermię Uniejów im. S. Olasa

Pomysł na innowacyjne wykorzystanie leczniczej wody geotermalnej w Uniejowie zakiełkował już w 2013 roku. Do prac zaproszono przedstawicieli środowiska naukowo-badawczego, którzy zaprezentowali szereg możliwości i koncepcji wykorzystania uniejowskiej wody w medycynie, lecznictwie oraz w przetwórstwie owoców i warzyw. Dnia 10 lutego 2014 roku gmina Uniejów podpisała porozumienie o współpracy z Instytutem Ogrodnictwa w Skierniewicach. W kolejnych latach, na zlecenie gminy i Geotermii Uniejów, w instytucie przeprowadzono szereg prac laboratoryjnych i mikrotechnicznych dotyczących możliwości wykorzystania wody bogatej w makro- i mikroelementy do produkcji mieszanych soków warzywnych bez dodatku soli kopalnej oraz do otrzymywania innowacyjnych produktów z warzyw kiszonych. Wyniki wstępnych prób w postaci soków pomidorowych na bazie wody z Uniejowa - bez dodatku soli - ujrzały światło dzienne w roku 2015. Duża ilość zawartych w wodzie związków mineralnych sprawiła, że końcowy produkt jest wartościowszy od przetworzonego na zwykłej wodzie, a brak dodatkowej soli (poza tą występującą naturalnie w wodzie) czyni go zdrowszym od tych tradycyjnych, dostępnych na rynku.

Równolegle do soków opracowywano receptury kiszonych warzyw, spośród których najwyższe oceny jakości i uznanie konsumentów uzyskały ogórki kiszone.

${ }^{23}$ W roku 2015 Ogórek Termalny z Uniejowa uzyskał świadectwo ochronne na zastrzeżony znak towarowy. Zabieg ten wpłynął korzystnie na wizerunek produktu, zwiększył jego konkurencyjność, ale też jest narzędziem marketingowym oddziałującym pozytywnie na klienta. 
Do współpracy zaproszono wówczas drugiego ze wspomnianych partnerów biznesowych - firmę Bracia Urbanek Sp. z o.o. z Łowicza, która chętnie podjęła się produkcji ogórków wedle wspomnianej receptury z wykorzystaniem wody termalnej z ujęć w Uniejowie ${ }^{24}$.

Uniejowski Ogórek Termalny jako modelowy efekt udanej współpracy samorządu, nauki i biznesu okazał się hitem sprzedażowym i promocyjnym. O renomie tego produktu świadczy wzrastająca sprzedaż, jego udział w akcjach promocyjnych oraz zainteresowanie organizatorów i uczestników targów spożywczych, ekologicznych, konferencji dotyczących żywienia etc. Podczas III Międzynarodowego Kongresu Promocji Warzyw i Owoców w Warszawie uniejowskie stoisko z Ogórkiem Termalnym z Uniejowa cieszyło się dużym zainteresowaniem odwiedzających. Ogórek Termalny był także motywem wiodącym Uniejowskiego Festiwalu Smaków w 2018 roku.

Uniejowski ogórek termalny sprzedawany jest zarówno w wiaderkach (poj. 5,75 kg / 3,0 kg), jak i w słoikach (poj. $660 \mathrm{~g} \mathrm{/} 450 \mathrm{~g}$ ). Wynika to z faktu, że jest on częściowo wykorzystywany przez restauratorów, którzy komponują dania z użyciem tego składnika. Natomiast słoiczki o wiele częściej funkcjonują jako pamiątka turystyczna, zatem z oczywistych względów mniejsza pojemność i cena zostały bardziej docenione przez klientów indywidualnych. W przypadku wiaderek największy wzrost produkcji odnotowano w 2018 roku, a więc rok po wprowadzeniu na rynek (o blisko 300\%), w kolejnych latach odnotowano nieznaczny spadek. $\mathrm{Z}$ kolei sprzedaż produktu $\mathrm{w}$ słoikach $\mathrm{z}$ każdym rokiem wykazuje tendencję wzrostową. Przyczyn można upatrywać w zwiększającej się liczbie turystów, ale również w coraz większej popularności miejsc dystrybucji. Ogórek Termalny dostępny jest w kilku lokalach gastronomicznych oraz w sklepach spożywczych na terenie Uniejowa, dzięki czemu jest bardziej eksponowany i widoczny.

Zastosowanie jako bazy wody termalnej wpływa nieco na smak produktu. Tym samym staje się on ciekawą propozycją jako pamiątka turystyczna z uzdrowiska, pozwalającą skosztować tego, co nietypowe i nigdzie indziej niespotykane i niedostępne.

\section{POZOSTAŁE PRODUKTY SPOŻYWCZE Z UŻYCIEM WODY TERMALNEJ}

Sukces kiszonki firmowanej marką Uniejów stał się inspiracją do dalszych poszukiwań receptur wzbogacających asortyment produktów lokalnych. W konsekwencji, w 2019 roku na rynek weszły kolejne produkty oparte na bazie wody

${ }^{24}$ M. Bartosiak, Ogórek termalny zadebiutowat!, 2017, https://uniejow.pl/aktualnosci/ogorek-termalny-zadebiutowal.html [dostęp: 7.06.2020]. 
termalnej - barszcz i żurek, produkowane przez firmę Hydrogroup z Uniejowa. Wyroby te nie zawierają konserwantów, a mąka do produkcji żurku i buraki do produkcji barszczu pochodzą od regionalnych dostawców. Ich dopełnieniem jest seria soków owocowych z dodatkiem uniejowskiej solanki oraz woda gazowana i niegazowana Thermal Uniejów produkowana w ramach współpracy z firmą Hellena, zarejestrowaną w Biernatkach, w podkaliskiej gminie Żelazków (ryc. 3).

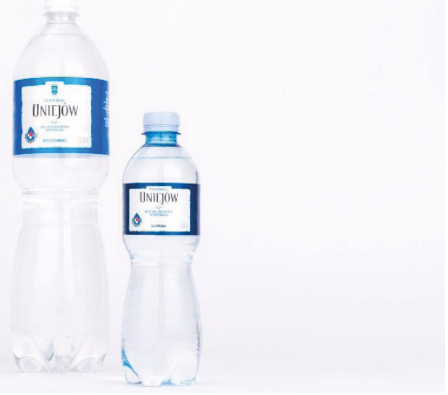

Ryc. 3. Woda mineralna Thermal Uniejów

Źródło: materiały udostępnione przez Geotermię Uniejów im. S. Olasa

Sprzedaż wody mineralnej, która została wprowadzona na rynek w ostatnim kwartale 2019 roku, na dzień 31.06.2020 wzrosła o ponad 100\%. Dane potwierdzają i wpisują się w panujący ogólnie wzrostowy trend w spożyciu wody mineralnej. Jest to wynikiem zainteresowania zdrowym żywieniem i stylem życia, dzięki czemu sprzedaż wód mineralnych nieprzerwalnie rośnie. Oczywiście wiele zależy od aury pogodowej, co przekłada się na różnice w sprzedaży w sezonie letnim w stosunku do zimowego, ale badania ogólnopolskie dowodzą jednoznacznie, że sektor ma przed sobą dobre perspektywy. T. Wojtaszek, prezes Krajowej Izby Gospodarczej „Przemysł Rozlewniczy”, zaznacza, że statystyczny Polak wypija rocznie od 75 do 85 litrów wody butelkowanej rocznie z tendencją wzrostową. Polski sektor wód mineralnych ma przed sobą przyszłość, chociażby z uwagi na fakt, że dla porównania Słowacy wypijają ok. 93 litry wód butelkowanych rocznie, Węgrzy - 122 1, Belgowie - 132 1, zaś Francuzi i Niemcy - niemal 140 litrów na osobę rocznie ${ }^{25}$. Pod tym względem wyprodukowanie wody mineralnej marki Uniejów, której bazę stanowi woda termalna, jest wyjątkowo udanym przedsięwzięciem.

W odniesieniu do soków owocowych ich sprzedaż w 2019 roku rozłożyła się dość równomiernie na poszczególne kwartały, z nieznaczną przewagą kwartału II. Trudno oszacować obecnie, o ile wzrośnie sprzedaż tegoroczna. Do końca

${ }^{25}$ Rośnie sprzedaż wody mineralnej, 2016, https://www.portalspozywczy.pl/napoje/wiadomosci/rosnie-sprzedaz-wody-mineralnej,117023.html [dostęp: 13.08.2020]. 
II kwartału 2020 roku produkcja soków na bazie wody termalnej wynosiła $80 \%$ całej ubiegłorocznej produkcji, co pozwala sądzić, że i w tym roku, mimo kryzysu związanego z pandemią, zostanie odnotowany wzrost.

Produkty spożywcze, podobnie jak Ogórek Termalny z Uniejowa, dostępne są w sklepach spożywczych, obiektach hotelarskich oraz w wybranych obiektach gastronomicznych. Jedno z miejsc dystrybucji zasługuje na szczególną uwagę - Zagroda Młynarska - zespół muzealno-noclegowy z czterema oryginalnymi zabytkowymi obiektami architektury drewnianej z XIX w., przeniesionymi z terenu województwa łódzkiego ${ }^{26}$. W celu zaspokojenia potrzeb żywieniowych turystów jeden z budynków przystosowano na potrzeby karczmy, w której można skosztować bogatej oferty lokalnych kulinariów, takich jak: miody z lokalnych pasiek, potrawy z warzyw z gospodarstwa ekologicznego. Niemal cały asortyment karczmy, zarówno ten uniejowski, jak i niefirmowany marką Uniejów (nalewki, miody pitne, kwas chlebowy, napoje czy słodkości), emanuje regionalnością. W ten sposób Zagroda Młynarska podkreśla swój lokalny charakter, a przebywając w obiekcie, można istotnie odnieść wrażenie, że czas zatrzymał się w miejscu. Produktem lokalnym jest cały kompleks w ujęciu holistycznym, od budynków, poprzez ich wystrój, aż po oferowany asortyment. Atmosfera miejsca zachęca turystów do zakupu uniejowskich wyrobów, a wyniki sprzedażowe wykazują, że czyni to $\mathrm{z}$ dużym powodzeniem.

\section{PIWO WIATR}

Uniejowski browar jest przykładem wykreowania wyrobu, któremu nadano wymiar produktu lokalnego, a następnie z dużym sukcesem przekuto w produkt turystyczny. Chociaż powstanie browaru nie było podyktowane przesłankami historycznymi, ten jeden z najstarszych trunków i elementów kultury materialnej człowieka ma swoje wielowiekowe uzasadnienie na ziemi uniejowskiej. Pierwsze wzmianki sięgają jeszcze początków miasta, wyprzedzając nawet czasy nadania mu praw miejskich. Przyczyniło się do tego położenie na szlaku handlowym przyciągające wielu handlarzy, obecność licznego duchowieństwa i klasztorów (notabene do niemal XII w. mnisi posiadali monopol na warzenie piwa ${ }^{27}$ ) oraz działalność cechów i rzemieślników. Szczegółowa analiza piwnych śladów i obecności trunku w historii Uniejowa na przestrzeni wieków stała się już przedmiotem odrębnego opracowania, prezentowanego na łamach „Biuletynu Uniejowskiego”28.

${ }^{26}$ J. Gontarz, Miejsce z historia, [w:] J. Gontarz (red.), Gorace źródta, Wyd. PGK Termy Uniejów, Uniejów 2018, s. 21.

${ }^{27}$ Tajemnice przyklasztornych winnic, 2018, http://gazetacodzienna.pl/artykul/kultura/tajemnice-przyklasztornych-piwnic [dostęp: 7.06.2020].

${ }^{28}$ J. Kałużny, Piwne ślady w Uniejowie, „Biuletyn Uniejowski” 2017, t. 6, s. 109-119. 
Wobec powyższego niniejsze studium ograniczy się do przyjrzenia się obecnej produkcji piwa w powstałym w $2016 \mathrm{r}$. browarze, która nie tylko odnowiła tradycję piwowarską na terenie Uniejowa, ale umacnia sukcesywnie jego funkcję turystyczną.

Uniejowskie piwo to odpowiedź na potrzeby konsumentów coraz bardziej znudzonych piwem przemysłowym. Strategia właścicieli obiektu jest dość prosta - stawiają na jakość, a nie na ilość. Przyznane złote medale dla piw Pils i Bock w krajowym Konkursie Piw Rzemieślniczych „Kraft Roku 2017” są tego dobitnym wyrazem. Zważywszy na fakt, że do konkursu zgłoszono ponad pół tysiąca piw, a samo wydarzenie należy do pięciu najliczniej obsadzonych konkursów piwnych w Europie ${ }^{29}$, Browar Wiatr ma powód do dumy, tym bardziej że ów ogromny sukces przyszedł w zaledwie rok po otwarciu lokalu (ryc. 4).

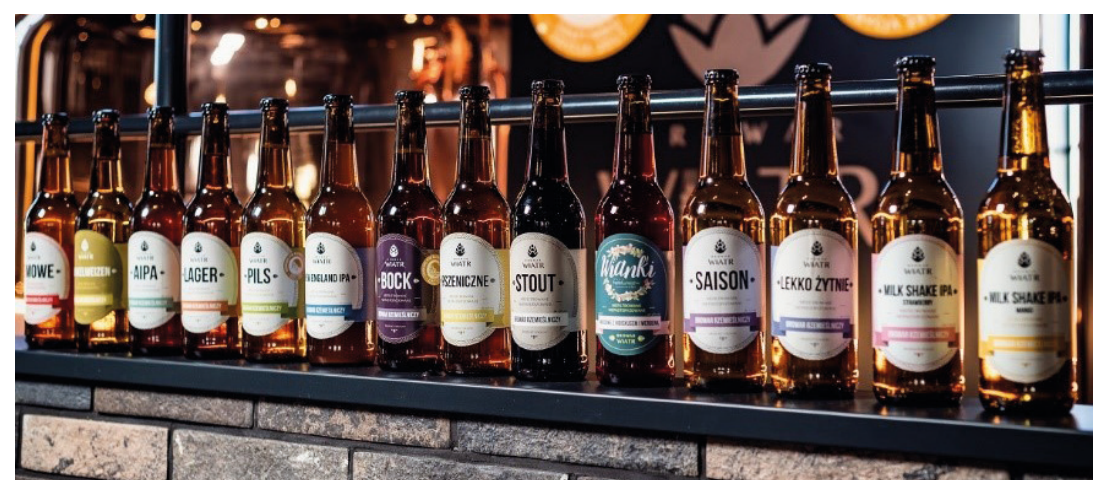

Ryc. 4. Piwo Wiatr

Źródło: materiały udostępnione przez dział marketingu Browaru Wiatr

Biesiadujący w browarze klienci mają okazję degustować trunek w miejscu jego warzenia, co bez wątpienia jest wartością dodaną. W odniesieniu do samej oferty asortyment obejmuje piwa klasyczne oraz piwa sezonowe z uwzględnieniem zmieniających się wraz z porami roku preferencji konsumentów. Surowce wykorzystane do produkcji pochodzą w miarę możliwości od lokalnych dostawców, przy tym są naturalne, pozbawione zbędnych konserwantów i ulepszaczy, co wprawdzie skraca termin ważności, ale w tym przypadku jest to akurat zaleta, gdyż konsumenci mają świadomość wyboru dobrego jakościowo produktu. Właściciele obiektu postawili na ekologiczną technologię, o niskim zużyciu wody i prądu oraz dodatkowym uzdatnieniu wody stosowanej w procesie produkcyjnym dla podniesienia walorów smakowych.

W browarze działa również restauracja, serwująca potrawy przygotowywane na bazie produktów pochodzących z regionu. Nie brakuje w tym miejscu twór-

${ }^{29}$ Kraft Roku 2017 - wyniki, 2017, http://www.kraftroku.pl/post/kraft-roku-2017-wyniki,9. html [dostęp: 7.06.2020]. 
czego podejścia do piwa, goście browaru mogą spróbować dań z dodatkiem piwa czy deseru beeramisu (do którego wykorzystano ciemne piwo zamiast kawy). Właściciele obiektu rozważają także podjęcie próby prezentacji procesu warzenia piwa, by zaznajomić gości z tajnikami rzemiosła, jakim jest browarnictwo. Wymiar edukacyjny mógłby stanowić interesujące uzupełnienie oferty biznesowej i znacząco uatrakcyjnić pobyt $\mathrm{w}$ browarze.

Jednak już teraz dostrzega się rosnące uznanie i popularność uniejowskiego browaru regionalnego, zarówno wśród lokalnej społeczności, jak i odwiedzających miejscowość turystów. Dzięki swej oryginalności staje się wizytówką, dodatkowym walorem turystycznym Uniejowa i obowiązkowym punktem na mapie miasta. Konsumenci chętnie zabierają piwa do domu jako pamiątkę, by dzielić się w swoim środowisku ich wyjątkowością.

\section{PRODUKTY NA BAZIE LAWENDY}

O ile wspomniane dotychczas produkty mają swoje uzasadnienie, czy to historyczne, czy geograficzne, wynikające z występujących na terenie Uniejowa zasobów naturalnych i tradycji, o tyle produkty na bazie lawendy są wytworem zupełnie nowym na tym terenie. Właściciele hotelu Medical Spa Hotel Lawendowe Termy uczynili z krzewu o wyjątkowym zapachu i właściwościach symbol i znak rozpoznawczy dla swojego biznesu, czego wyrazem jest fakt, że hotel obsadzony jest blisko 4000 sadzonek tej rośliny, przywodzących na myśl krajobrazy prowansalskich pól.

Właściwości i zastosowanie lawendy stało się jednym z elementów strategii biznesowej. Na terenie obiektu serwuje się potrawy z dodatkiem lawendy, część z nich, jak np. nalewki, konfitury, syropy czy czekolady własnej produkcji można zakupić jako pamiątkę.

Na bazie lawendy powstała również seria wyrobów kosmetycznych, takich jak woda, mydełko, olejek, sól do kąpieli (połączenie naturalnego suszu z solą kłodawską) oraz rękodzielnicze elementy dekoracyjno-zapachowe i woreczki z suszem.

Ponadto nieprzerwanie od kilku lat $\mathrm{w}$ ramach strategii marketingowej hotel organizuje festiwal tematyczny pod nazwą Ogólnopolski Festiwal Lawendy, który z roku na rok przyciąga coraz więcej wystawców, jak i turystów. Wydarzenie odbywa się w okresie kwitnienia krzewu, co niewątpliwie jest wartością, gdyż intensywny i przyjemny zapach jako forma marketingu sensorycznego potrafi zachęcić do zakupu skuteczniej niż każdy inny rodzaj reklamy.

Nie sama sprzedaż jest jednak w tym przypadku kluczowa, a umiejętne wykorzystanie produktu jako narzędzia promocyjnego, zarówno dla samego obiektu, jak i dla miasta - służy zaprezentowaniu Uniejowa jako prężnego, atrakcyjnego 
ośrodka kulturalnego z unikatową ofertą turystyczną, zapleczem kulturalnym i artystycznym.

Podobnie jak w przypadku produktów na bazie wody termalnej artykuły lawendowe są wykreowane od podstaw, a dzięki działaniom promocyjnym wyszły poza funkcję gadżetu hotelowego, stając się jednym z produktów uniejowskich stanowiących wyróżnik całej gminy - jej tożsamości, walorów i oferty.

$\mathrm{Z}$ informacji uzyskanych z działu marketingu obiektu hotelowego wynika, że największym zainteresowaniem cieszą się wytwory z tzw. Manufaktury Lawendowych Term, a więc produkty spożywcze wykreowane przez szefa kuchni Urszulę Czyżak w postaci domowych konfitur czy napitków z lawendą (ryc. 5).

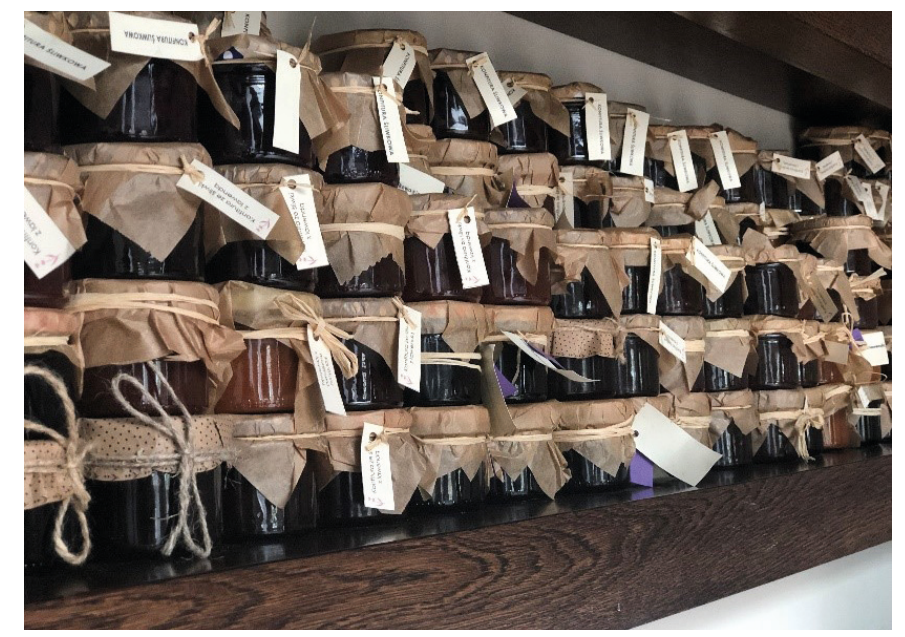

Ryc. 5. Konfitury z dodatkiem lawendy z Manufaktury Lawendowych Term

Źródło: materiały udostępnione przez dział marketingu Medical Spa Hotel **** Lawendowe Termy

Wyznacznikiem ich sukcesu jest choćby fakt, że goście często wracają po zakupione produkty. Przytoczono przykłady osób, które pokonują znaczne odległości lub czekają kilka miesięcy, aby po raz kolejny rozsmakować się w wypróbowanych specjałach, jak np. nalewka z czarnego bzu dostępna wyłącznie w sezonie letnim. Klienci zwracają często uwagę na własnoręczne wykonanie produktów, doceniają sezonowość i możliwość ich personalizacji. Ostatnie lata pokazały także wzmożone zainteresowanie produktami i gadżetami z użyciem lawendy, nabywanymi jako pamiątka lub prezent dla bliskich. Zainteresowanie produktami plasuje się na podobnym poziomie przez cały rok, $\mathrm{z}$ wyszczególnieniem sezonu przedświątecznego, gdy wiele z nich nabywanych jest jako prezent pod choinkę. 


\section{LOKALNE PRODUKTY A ROZWÓJ I PROMOCJA GMINY UNIEJÓW}

Uniejowskie produkty lokalne jako komponent oferty turystycznej są dużą szansą dla obszaru. Z uwagi na specyfikę łączą w sposób praktyczny kulturę i zwyczaje z aspektem ekonomicznym stają się czynnikiem zachęcającym mieszkańców i odwiedzających do podejmowania dodatkowej aktywności ekonomicznej, a także podnoszą atrakcyjność gminy i wzbogacają jej wizerunek. Lokalne wyroby stają się również swoistym elementem integrującym społeczność lokalną, wzmacniającym jej poczucie tożsamości, przynależności do lokalnej tradycji i zasobów, wokół którego skupia się uwaga mieszkańców i przekonanie o wyjątkowości miejsca, w którym żyją na co dzień.

$\mathrm{W}$ tworzeniu oferty produktów uniejowskich rolę wiodącego podmiotu pełni samorząd z uwagi na duży potencjał środków i rozległe kompetencje. Przykład kosmetyków i wyrobów spożywczych na bazie wody termalnej, w których produkcję i promocję zaangażowały się władze lokalne, jest wyrazem kreatywnego i innowacyjnego podejścia do prowadzonej polityki lokalnej i pokazuje, w jaki sposób wykorzystanie walorów przyrodniczych w odpowiedniej otoczce marketingowej może prowadzić do budowania marki od podstaw. W warunkach wszechogarniającej konkurencyjności i przewagi podaży nad popytem rynek nie może ograniczyć się do towarów ,jakichkolwiek”, muszą one być coraz lepsze i nietuzinkowe. Pod tym względem wykorzystanie wody termalnej w przetwórstwie spożywczym było pionierskim zabiegiem i stanowi fenomen w skali ogólnopolskiej.

Warto również uwzględnić fakt, że promowanie produktów spożywczych zarówno, termalnych, jak i innych przedstawionych w artykule, ma duże znaczenie dla rozwoju aktywności turystycznej. W ostatnich latach turystyka kulinarna wykazuje ogromny potencjał, a poznawanie lokalnych tradycji żywieniowych jest często ważnym motywem wyjazdu. Trafnym przykładem wydarzenia kulinarnego, przyciągającego coraz większe rzesze odwiedzających, jest coroczny Uniejowski Festiwal Smaków, organizowany od 2014 r. w formie smakowitych spacerów po Uniejowie, stanowiący „bitwę na smaki”, angażującą lokalnych restauratorów. Dzięki promocji wydarzenie szybko nabrało rozmachu i z roku na rok powiększa swój zasięg, przyciągając gości z innych województw ${ }^{30}$.

O ile jednak motywy kulinarne mogą być głównym powodem planowanego wyjazdu, o tyle zakup pamiątek jest czynnością towarzyszącą, ale na tyle istotną, że dla wielu turystów doświadczenie podróży nie może być w pełni satysfakcjonujące bez pamiątki. Zakup choćby drobiazgu pełni funkcję przypominającą o danym miejscu lub zdarzeniu i podtrzymującą związek z podróżą. M. Banaszkiewicz twierdzi, że wręczenie prezentu po powrocie bliskim lub znajomym można po-

${ }^{30}$ A. Owczarek, K. Smętkiewicz, Strategia rozwoju turystyki kulinarnej na przykladzie Festiwalu Smaków w Uniejowie, „Biuletyn Uniejowski” 2019, t. 8, s. 115-130. 
traktować jako „chęć włączenia osób niebędących uczestnikami naszej podróży i podkreślenia naszej relacji z daną osobą" ${ }^{31}$. Wyjątkowość pamiątek kulinarnych tkwi w możliwości posmakowania po powrocie tego, co trudne lub niemożliwe do znalezienia nigdzie indziej.

Produkty lokalne mogą być zatem skutecznym czynnikiem wzmagającym ruch turystyczny, narzędziem promocyjnym dla miasta poza jego granicami, ale przynoszą również korzyści w kontekście rozwoju społeczno-gospodarczego. Wytwarzanie produktów daje bowiem możliwość podniesienia dochodów, tworzy miejsca pracy i może wpłynąć na ogólną poprawę jakości życia.

Produkty regionalne, zwłaszcza żywnościowe, są pierwszym ogniwem łączącym turystę z regionem, a korzystanie z lokalnych produktów (nie tylko spożywczych) w dużej mierze wpływa na wrażenia, jakie pozostają z podróży.

Mając na uwadze, że polscy konsumenci coraz chętniej sięgają po produkty lokalne naturalne, bez ulepszaczy i sztucznych dodatków, trend ten stanowi podstawę do aktywizacji gospodarki i wykreowania solidnej marki regionu. Ta z kolei, jako wspólny mianownik dla różnych artykułów, tworzy spójny i klarowny przekaz, który przemawia do konsumenta. Wykreowanie oferty wyrobów pod wspólnym szyldem daje możliwość różnorodności, angażującej w sposób zintegrowany więcej podmiotów, które działając samodzielnie, nie byłyby w stanie osiągnąć takich efektów. Otoczka znanej i wzbudzającej zainteresowanie marki ułatwia wprowadzenie nowych produktów na rynek oraz prowadzenie efektywnych działań promocyjnych.

\section{PODSUMOWANIE}

Uniejów, pomimo swej burzliwej historii i zmiennych kolei losu, posiada duży potencjał tworzenia ciekawych produktów lokalnych, które odpowiednio wykreowane i sprzedane, mogą być skutecznym narzędziem promocyjnym. Jak zauważa A.B. Cieślak, wartość miasteczka rośnie wprost proporcjonalnie do posiadanych zasobów kulturowych ${ }^{32}$. Opisane przykłady wykorzystania wytworów lokalnych do wzmocnienia funkcji turystycznej potwierdzają, że oferta rodzimych produktów jest czynnikiem napędzającym rozwój danego obszaru.

O ile produkty lokalne zazwyczaj stanowią element dziedzictwa po poprzednich pokoleniach, produkty uniejowskie nie posiadają uwarunkowanej historycznie genezy ani tożsamości kulturowej. Wyjątek pod tym względem stanowi piwo, które jest częścią wielowiekowej tradycji miasta.

${ }^{31}$ M. Banaszkiewicz, Pamiątki turystyczne - w poszukiwaniu tożsamości, „Turystyka Kulturowa" 2011 , nr 4, s. 5.

32 A.B. Cieślak, Historyczne centrum Uniejowa w kontekście rozwoju funkcji uzdrowiskowej - rola i znaczenie, „Biuletyn Uniejowski” 2015, t. 4, s. 5-24. 
Głównym problemem na drodze do powstawania lokalnego rynku było przede wszystkim znalezienie surowca, na którym można oprzeć linię produkcyjną. W tej kwestii bez wątpienia wiodącą rolę pełni woda termalna, na bazie której powstała bogata oferta wyrobów kosmetycznych, jak i jej pionierskie wykorzystanie w przetwórstwie spożywczym.

Przygotowanie oferty produktów, która zachęci i przyciągnie turystów, wymaga jednak współpracy i skorelowanych działań samorządu, przedsiębiorców, jak również samych mieszkańców, które prowadzą do wykreowania produktu i podjęcia inicjatyw promocyjnych poprzez działania marketingowe.

Innowacyjne i kreatywne podejście lokalnych liderów pozwoliło stworzyć ofertę dóbr, które stanowią unikatowy walor, a atrakcyjność i oryginalność produktów uniejowskich niewątpliwie kształtują wizerunek Uniejowa i podnoszą jego rozpoznawalność.

\section{Bibliografia}

Banaszkiewicz M., Pamiątki turystyczne - w poszukiwaniu tożsamości, „Turystyka Kulturowa” 2011, nr 4, s. 5.

Bednarek-Szczepańska M., Bański J., Lokalizacyjne uwarunkowania oferty gospodarstw agroturystycznych w Polsce, „Przegląd Geograficzny” 2014, t. 86, z. 2, s. 243-260.

Cieślak A.B., Historyczne centrum Uniejowa w kontekście rozwoju funkcji uzdrowiskowej - rola i znaczenie, „Biuletyn Uniejowski” 2015, t. 4, s. 5-24.

Czerwińska-Jaśkiewicz M. Znaczenie produktów lokalnych w różnicowaniu oferty turystycznej regionu, „Zeszyty Naukowe Uniwersytetu Szczecińskiego. Problemy Zarządzania, Finansów i Marketingu" 2013, nr 30, s. 305-313.

Gontarz J., Solanka w produktach geotermalnych, „Gorące Źródła. Magazyn Term Uniejów” 2017, s. 24-25.

Gontarz J., Miejsce z historia, „Gorące Źródła. Magazyn Term Uniejów” 2018, s. 21.

Kaczmarek J., Stasiak A., Włodarczyk B., Produkt turystyczny: pomyst, organizacja, zarzadzanie, Polskie Wydawnictwo Ekonomiczne, Warszawa 2010, s. 110-111.

Kaczmarek J., Stasiak A., Włodarczyk B., Produkt turystyczny, „Turystyka i Hotelarstwo” 2010, s. 35.

Kałużny J., Piwne ślady w Uniejowie, „Biuletyn Uniejowski” 2017, t. 6, s. 109-119.

Kruczek Z, Polska geografia atrakcji turystycznych, Wyd. Proksenia, Kraków 2011, s. 12-14.

Kulawiak A., Rachwał T., Smętkiewicz K., Wpływ inwestycji infrastrukturalnych, przemysłowych i mieszkaniowych na rozwój ukladów lokalnych na przykładzie gminy Uniejów w województwie łódzkim, „Prace Komisji Geografii Przemysłu Polskiego Towarzystwa Geograficznego” 2018, t. 32, nr 3, s. 69-97.

Milne S., Ateljevic I., Tourism, economic development and the global-local nexus: theory embracing complexity, „Tourism Geographies” 2001, t. 3, nr 4, s. 369-393.

Nizioł A., Rola produktów lokalnych w rozwoju funkcji turystycznej regionu na przykładzie Podkarpacia, „Annales Universitatis Mariae Curie-Skłodowska, sectio B - Geographia, Geologia, Mineralogia et Petrographia" 2016, t. LXXI, z. 2, s. 105. 
Owczarek A., Smętkiewicz K., Strategia rozwoju turystyki kulinarnej na przykładzie Festiwalu Smaków w Uniejowie, „Biuletyn Uniejowski” 2019, t. 8, s. 115-130.

Sieczko A., Tworzenie rynku produktów tradycyjnych i regionalnych, „Zeszyty Naukowe SGGW w Warszawie. Problemy Rolnictwa Światowego" 2008, t. 4, nr 19, s. 397.

Suliborski A., Gospodarka i warunki bytowe po II wojnie światowej, [w:] J. Szymczak (red.), Uniejów. Dzieje miasta, Wydawnictwo Towarzystwa Przyjaciół Uniejowa, Łódź-Uniejów 1995, s. 319.

Szymczak J., Uniejów do schytku XVI wieku, [w:] J. Szymczak (red.), Uniejów. Dzieje miasta, Wydawnictwo Towarzystwa Przyjaciół Uniejowa, Łódź-Uniejów 1995, s. 59-70.

Witkowski L.P., Biblioteka Warszawska, pismo poświęcone naukom, sztukom i przemysłowi, Drukarnia Gazety Codziennej, tom drugi, Warszawa 1855, s. 411.

\section{Źródla internetowe}

Bartosiak M., Ogórek termalny zadebiutowat!, 2017, https://uniejow.pl/aktualnosci/ogorek-termalny-zadebiutowal.html [dostęp: 7.06.2020].

Bartosiak M., Termalne kosmetyki nowym produktem regionalnym, https://uniejow.pl/aktualnosci/ termalne-kosmetyki-nowym-produktem-regionalnym.html [dostęp: 7.06.2020].

Bosak W., Wielkopolskie wspomnienia, 2011, http://www.vinisfera.pl [dostęp: 7.06.2020].

Kraft Roku 2017, wyniki, http://www.kraftroku.pl/post/kraft-roku-2017-wyniki,9.html [dostęp: 7.06.2020]

Historia spoleczności, 2020, https://sztetl.org.pl/pl/miejscowosci/u/527-uniejow/99-historia-spolecznosci/138202-historia-spolecznosci [dostęp: 6.08.2020].

Jaka jest różnica pomiędzy produktem regionalnym a produktem tradycyjnym?, 2016, http://szlakiembeskidu.pl/2-uncategorised/244-jaka-jest-roznica-pomiedzy-produktem-tradycyjnym-a-regionalnym.html [dostęp: 13.08.2020].

Polska w Unii Europejskiej, 2020, https://pl.wikipedia.org/wiki/Polska_w_Unii_Europejskiej [dostęp: 13.08.2020].

Produkt lokalny, 2020, https://pl.wikipedia.org/wiki/Produkt_lokalny [dostęp: 13.08.2020].

Rośnie sprzedaż wody mineralnej, 2016, https://www.portalspozywczy.pl/napoje/wiadomosci/rosnie-sprzedaz-wody-mineralnej,117023.html [dostęp: 13.08.2020].

Tajemnice przyklasztornych winnic, 2018, http://gazetacodzienna.pl/artykul/kultura/tajemnice-przyklasztornych-piwnic [dostęp: 7.06.2020].

\section{LOCAL PRODUCTS OF UNIEJÓW AS A TOOL FOR PROMOTING THE COMMUNE AND A SOUVENIR FROM JOURNEY}

\section{Summary}

One of the trends in modern tourism is interest in the local and regional heritage. New consumer trends such as ethnocentrism, growing interest in native products or the greening of production are clearly visible on fairs and local markets, where consumers are looking for unique products made from raw materials of known origin, with unique organoleptic qualities. 
In the case of Uniejów commune, the market of local products is in the development phase, although local authorities and entrepreneurs see in them an effective tool for building a tourist brand and promotional factor. Local products from Uniejów start to function as journey souvenirs, and sales results confirm their marketing power, which creates new perspectives in the context of demand for native goods. The purpose of this study is to show through selected examples of the current range of Uniejów products how local resources can be used and how the product offer can impact the image and popularization of the tourist offer of Uniejów commune.

Keywords: local marketing, local product, product, promotion, Uniejów.

Data nadesłania artykułu: czerwiec 2020

Data akceptacji: sierpień 2020 